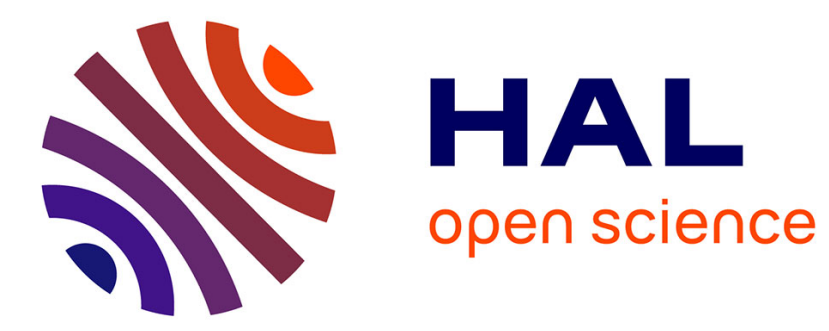

\title{
Deer slow down litter decomposition by reducing litter quality in a temperate forest
}

Simon Chollet, Morgane Maillard, Juliane Schörghuber, Sue J Grayston, Jean-Louis Martin

\section{- To cite this version:}

Simon Chollet, Morgane Maillard, Juliane Schörghuber, Sue J Grayston, Jean-Louis Martin. Deer slow down litter decomposition by reducing litter quality in a temperate forest. Ecology, 2021, 102 (2), pp.e003235. 10.1002/ecy.3235 . hal-03046927

\section{HAL Id: hal-03046927 \\ https://hal.science/hal-03046927}

Submitted on 8 Dec 2020

HAL is a multi-disciplinary open access archive for the deposit and dissemination of scientific research documents, whether they are published or not. The documents may come from teaching and research institutions in France or abroad, or from public or private research centers.
L'archive ouverte pluridisciplinaire HAL, est destinée au dépôt et à la diffusion de documents scientifiques de niveau recherche, publiés ou non, émanant des établissements d'enseignement et de recherche français ou étrangers, des laboratoires publics ou privés. 
Article type : Articles

Journal: Ecology

Manuscript type: Article

Running Head: Deer slow down litter decomposition

\section{Deer slow down litter decomposition by reducing litter quality in a temperate forest}

Simon Chollet ${ }^{1 *}$, Morgane Maillard ${ }^{2,3}$, Juliane Schörghuber ${ }^{4}$, Sue J. Grayston ${ }^{3}$, Jean-Louis Martin ${ }^{2}$

${ }^{1}$ Rennes 1 University, ECOBIO UMR CNRS 6553, France

${ }^{2}$ Centre d'Écologie Fonctionnelle et Évolutive, UMR 5175, CNRS - Université de Montpellier -

Université Paul Valéry - EPHE - IRD, France

${ }^{3}$ Faculty of Forestry, University of British Columbia, Vancouver, British Columbia, Canada

${ }^{4}$ Research Group on Introduced Species, Queen Charlotte, British Columbia, Canada

*Corresponding author.E-mail: simon.chollet@univ-rennes 1.fr

This article has been accepted for publication and undergone full peer review but has not been through the copyediting, typesetting, pagination and proofreading process, which may lead to differences between this version and the Version of Record. Please cite this article as doi: 10.1002/ECY.3235

This article is protected by copyright. All rights reserved 


\begin{abstract}
Litter decomposition is a key process that allows the recycling of nutrients within ecosystems. In temperate forests the role of large herbivores in litter decomposition remains a subject of debate. To address this question, we used two litterbag experiments in a quasi-experimental situation resulting from the introduction of Sitka black-tailed deer Odocoileus hemionus sitkensis on forested islands of Haida Gwaii (Canada). We investigated the two main pathways by which deer could modify litter decomposition: change in litter quality and modification of decomposer communities. We found that deer presence significantly reduced litter mass loss after one year, mainly through a reduction in litter quality. This mass loss reflected a 30 and $28 \%$ lower loss of carbon $(\mathrm{C})$ and nitrogen $(\mathrm{N})$, respectively. The presence of deer also reduced the ability of decomposers to breakdown carbon, but not nitrogen. Indeed, litter placed on an island with deer lost 5\% less carbon after one year of decomposition than did litter decomposing on an island without deer. This loss in ability to decompose litter in presence of deer was outweighed by the differences in mass loss associated with the effect of deer on litter quality. Additional effects of feces deposition by deer on the decomposition process were also significant but minor. These results suggest that the effects continental-scale dramatic increases in deer populations may have on broad-scale patterns of $\mathrm{C}$ and $\mathrm{N}$ cycling deserve closer attention.
\end{abstract}

Keywords: decomposition, deer, forests, functional traits, Home-field Advantage, litter diversity effects, macro and meso fauna, top-down control

This article is protected by copyright. All rights reserved 


\section{Introduction}

Deer and the functioning of temperate forests

By the mid- $20^{\text {th }}$ century wild ungulates, essentially deer, were largely missing from temperate forests of Europe and eastern North America, a result of hunting and/or loss of favorable land cover (McShea et al. 1997, Apollonio et al. 2010). Since then, changes in hunting regulations, in land-uses, and the absence of their natural predators (Côté et al. 2004, Milner et al. 2006), allowed a dramatic rebound in deer populations. In less than a century the deer population in Europe is estimated to more than 15 million, and 30 million white-tailed deer (Odocoileus virginianus) alone inhabit North America (McShea et al. 1997, Apollonio et al. 2010). This rebound brought deer to the forefront of ecological thinking (Terborgh and Estes 2013).

Initially research focused on the consequences of deer recovery on forest vegetation, beginning with impacts on tree regeneration and growth (Gill 1992). More recent studies focused on aboveground understory community functioning (Horsley et al. 2003, Royo et al. 2010) with a focus on effects cascading on invertebrates, birds and small mammals (e.g. Chollet and Martin 2013, Foster et al. 2014)]. In the latter part of the $20^{\text {th }}$ century, the effect of large herbivores on processes of nutrient cycling in temperate forests also drew attention (Pastor et al. 1993, Frank and Groffman 1998, Ritchie et al. 1998, Olofsson and Oksanen 2002, Tanentzap and Coomes 2012). However, the repercussions of high deer densities on belowground patterns and processes are still insufficiently understood (Bardgett \& Wardle, 2003; Hobbie \& Villéger, 2015). These belowground effects will partly result from the effects deer have on litter decomposition, a pivotal link between aboveground primary production and belowground processes (Chapin et al. 2011). Contrary to grasslands or boreal forests, there are still only a few studies on how large herbivores affect litter decomposition in temperate forest ecosystems.

\section{Deer and litter decomposition}

Deer may modify litter decomposition by affecting litter quality. Through plant removal, combined with selective foraging, deer modify plant community composition, plant stoichiometry, as well as the relative contribution of canopy and understory vegetation to litter composition (Côté et al. 2004). Specifically, deer induce the production of anti-herbivore compounds by plants, which decrease litter

This article is protected by copyright. All rights reserved 
quality for decomposers (Harrison and Bardgett 2003). In addition, deer promote unpalatable plant species through preferential browsing of the most palatable species (Pastor et al. 1993). Because some of the traits controlling litter palatability and decomposability are similar, such a long-term plant community shift is expected to change litter decomposability (Bardgett and Wardle 2003). Overall, the expected reductions in litter quantity and quality should slow down decomposition processes and nutrient cycling (Bardgett and Wardle 2003). Deer also release dung and urine, a source of organic matter more easily decomposable than recalcitrant plant litter (Ruess and McNaughton 1987). Conversely to the reduction in litter quality due to the modification of the plant community, waste deposition by deer may speed up litter decomposition (Bardgett and Wardle 2003).

Deer may also modify litter decomposition by affecting decomposers ability to degrade litter (i.e. differences in decomposition rates of a given litter due to decomposers, Keiser et al. (2014)). The long-term changes deer generate in the vegetation could indeed trigger changes in decomposer communities that specialize them in decomposing the type of litter that falls locally, potentially compensating the aforementioned slowing down of decomposition rate. Such specialization of the decomposers for local litter is known as "home-field advantage" (HFA), and could play an important role in the decomposition process (Gholz et al. 2000, Austin et al. 2014). Yet, studies explicitly evaluating at the same time the role of the shift in vegetation induced by herbivores and the role of HFA are scarce and provided contrasting results (see Olofsson and Oksanen 2002, Penner and Frank 2018).

Besides the abovementioned effects of deer on decomposers ability via vegetation replacement, decomposers may also be affected directly by deer. Dung and urine represent a source of inorganic nitrogen for soil decomposers that enhances their development (Sitters et al. 2017). This may affect the structure and functioning of the decomposer communities, soil fauna (Andriuzzi and Wall 2017) and soil microorganisms (Cline et al. 2017, Eldridge et al. 2017), in ways that increase the rate of litter decomposition (Handa et al. 2014). Deer are also suspected to affect edaphic properties by increasing soil temperature and salinity through exposure of bare soil after vegetation removal by browsing, or by increasing soil compaction through trampling, with effects on soil water and oxygen content (Schrama et al. 2013). Such modifications of the soil may also alter the decomposer ability to degrade litter.

This article is protected by copyright. All rights reserved 


\section{A quasi-experimental context to test predictions on how deer affect litter decomposition}

Although the multiplicity of pathways through which deer can affect litter decomposition is recognized (see Bardgett and Wardle (2003) for a conceptual model), our knowledge is mainly based on the independent study of single pathways. This has led to apparent contradictions in results. To better identify the mechanisms behind the effect of deer on litter decomposition we designed a study that combined approaches to better assess of the relative effects of different pathways. Our study design benefitted from the long-term effort to use the late $19^{\text {th }}$ century introduction of Sitka blacktailed deer Odocoileus hemionus sitkensis to the Haida Gwaii archipelago (British Columbia, Canada, Golumbia et al. 2008) as an unplanned experiment on trophic interactions. Deer colonized most, but not all, islands of the archipelago. This resulted in a situation with, side by side, islands colonized by deer, and islands never colonized. This unique situation allowed to demonstrate that, in presence of deer, and independently of island size, deer herbivory was the main factor structuring plant, invertebrate and songbird communities, overwhelming other biotic or abiotic factors [i.e. island area, soil and micro-habitat diversity (Martin and Baltzinger 2002, Gaston et al. 2006, Martin et al. 2010, Chollet et al. 2013b)]. In addition recurrent experimental culls on some islands allowed to document a partial recovery of the aboveground vegetation and songbirds (Chollet et al. 2016).

We made use of these contrasts in deer browsing history in two decomposition experiments designed to test five predictions: 1) decomposition of litter collected from an island without deer would be faster than decomposition of the litter collected from an island with deer because of a decreased in litter quality in presence of deer (litter quality effect); 2) decomposition of a given category of litter (deer present or not) will be favored on the island from which that litter was collected (HFA effect); 3) decomposition ability would be higher in presence of deer because of changes in microbial communities in response to a more recalcitrant litter (decomposer ability effect); 4) presence of deer excrement would locally speed up the decomposition of plant litter; 5) decomposition pattern found on an island with partial understory recovery (cull island) would fall in between what we observe on the islands with and without deer.

This article is protected by copyright. All rights reserved 


\section{Materials and Methods}

\section{The archipelago and deer effect on the vegetation}

Haida Gwaii is characterized by a humid temperate-oceanic climate, with mean annual temperature of $8.5^{\circ} \mathrm{C}$ and precipitation that varies greatly from $1,350 \mathrm{~mm}$ on the east coast, where this study took place, to 7,000 $\mathrm{mm}$ on the west coast (Banner et al. 2014). The archipelago is covered by temperate rainforests dominated, at low elevation, by western hemlock (Tsuga heterophylla), western redcedar (Thuja plicata), and Sitka spruce (Picea sitchensis). The selected study sites belonged all to the Coastal Western Hemlock Wet Hypermaritime biogeoclimatic variant [Biogeoclimatic Ecosystem Classification, code CWHwh1, British Columbia Ministry of Forests, Lands, and Natural Resource Operations 2010)] which covers $49 \%$ of the archipelago, and ranges from sea-level to $350 \mathrm{~m}$ in elevation (Banner et al. 2014).

Because of the extensive effect deer had on the understory vegetation, islands can be segregated today into three categories of browsing histories and their associated vegetation patterns. Islands without deer, which are characterized by a diverse and lush understory vegetation dominated by broad leaved shrubs and ferns, producing a diverse and abundant litter. Islands where deer have been present for over 70 years, which are characterized by an open understory dominated by bryophytes where litter is dominated by conifer leaves (Stockton et al. 2005, Martin et al. 2010). Finally, islands where deer have also been present for over 70 years but have been subjected to recurrent deer culls. Their understory is characterized by an intermediate cover of vegetation (Chollet et al. 2016).

Study sites and plot selection

We selected three islands in Laskeek Bay (52 53'12"N, 131 $35^{\prime} 20^{\prime \prime} \mathrm{W}$, Appendix S1 in Supporting Information), Low, Reef and Louise Island. We chose sampling and experimental sites with similar bedrock geology, which was part of the Yakoun formation, consisting of porphyritic andesite agglomerate, calcareous scoraceous lapilli tuff and volcanic sandstone and agglomerate (Sutherland Brown 1968). The soil type was organic and classified into the Folisol order (Soil Classification Working Group / Groupe de travail sur la classification des sols 1998). These islands were representative of the patterns of deer impacts we documented at the scale of the archipelago (Martin et al. 2010, Chollet et al. 2015, Appendix S2 for a synthesis of previous studies). Low Island, 9.6 ha, that 
had never been colonized by deer, Louise Island, 25,000 ha, that has had deer for over 70 years (Vila et al. 2004) and had a current deer density estimated at 30 deer $/ \mathrm{km}^{2}$, and Reef Island, $249 \mathrm{ha}$, that had also been colonized by deer more than 70 years ago, but its deer population had been regularly culled between 1997 and 2010. At the time of study Reef Island had a deer population density estimated at about 15 deer / $\mathrm{km}^{2}$ and a partially recovered understory vegetation (Chollet et al. 2016). All islands were covered by tree species characteristic of the Coastal Western Hemlock Wet Hypermaritime biogeoclimatic zone, typical of the archipelago lowlands. Our emphasis on selecting sites similar in parent material prevented us from also controlling for island size. It also allowed us to minimize pseudo-replication by duplicating the experiment on additional islands, a duplication, however, that would have been a logistical challenge exceeding our means. To avoid potential biases due to elevation we selected all sampling plots at low elevation on the three islands with most plot elevations less than $50 \mathrm{~m}$ asl and never exceeding $100 \mathrm{~m}$ asl. Adjacent plots had to be separated by at least $100 \mathrm{~m}$. On each island, and within the constraints just stated, we randomly established fifteen 10 $\mathrm{m} \times 10 \mathrm{~m}$ forest interior plots, leading to a total of 45 plots.

\section{Above and belowground characteristics in relation to deer presence}

In each plot we sampled the vegetation by estimating the percent cover of vascular plants and bryophytes using the Londo scale (Londo 1976). We measured soil bulk density at the surface of the soil with five replicate measures per plot. For this, we collected soil with a $5.4 \mathrm{~cm}$ depth x $4.1 \mathrm{~cm}$ diameter $\left(71.29 \mathrm{~cm}^{3}\right)$ copper core hammered into the soil using a mallet. We took care to not change the structure of the soil while sampling. We removed any coarse woody-debris from core samples and subtracted their volume from the volume of the core. We then dried soil at $105^{\circ} \mathrm{C}$ for $24 \mathrm{~h}$ to obtain a value for bulk density expressed as $\mathrm{g}$ of dried soil per $\mathrm{cm}^{3}$ of fresh soil.

We used data on soil $\mathrm{pH}, \mathrm{C}: \mathrm{N}$ and organic horizon depth collected in the course of a sister study in plots located in the same area on these same islands (Maillard et al. unpublished data). This data was collected from five plots on Low Island, five plots on Louise Island and six plots on Reef Island. We sampled soil within these plots with a $2.5 \mathrm{~cm}$ diameter $\mathrm{x} 30 \mathrm{~cm}$ depth core collecting approximately 100 cores per plot. They were mixed and sieved with a $5 \mathrm{~mm}$ sieve to ensure homogenization, as recommended for soil with high content of organic matter (Haynes and Swift 1990). We measured soil $\mathrm{pH}$ in a $0.01 \mathrm{M} \mathrm{CaCl} 2$ solution using a 1:10 ratio (air dried soil: solution).

This article is protected by copyright. All rights reserved 
We determined soil C:N ratio from $3 \mathrm{mg}$ of freeze-dried and ground soil using an Elementar Vario El Cube Analyzer. In each plot we measured the depth of the soil's organic horizon from a soil pit dug within the plot.

\section{Experimental design and protocol}

To analyze how the prolonged presence of abundant deer affected litter decomposition, we designed two litterbag experiments centered on the three browsing treatments available: deer absent (no browsing, our reference), deer culled (intermediate browsing), and deer present (severe browsing).

We measured litter decomposition rates using the litterbag method. We made $15 \mathrm{~cm}$ x $15 \mathrm{~cm}$ bags using polypropylene mesh with two different mesh sizes. We used the litterbags with a $0.2 \mathrm{~mm} \mathrm{x}$ $0.2 \mathrm{~mm}$ mesh size to target the decomposition solely due to the soil microfauna and microorganisms. We used litterbags with a $3.7 \times 4.45 \mathrm{~mm}$ mesh size to assess the additional effect of the mesofauna and macrofauna on litter decomposition. For these large mesh litterbags, we used a $0.2 \mathrm{~mm} \times 0.2 \mathrm{~mm}$ mesh size on the bottom of the bag to avoid litter spillage.

To obtain our litter samples, we collected summer senescent leaves from plant species with a percent cover on the plots greater than $5 \%$. In total, we sampled 18, 20 and 17 plants species, respectively, on the island with no browsing, on the island with an intermediate level of browsing, and on the island with a severe level of browsing (Appendix S3). We dried these litter samples at $30^{\circ} \mathrm{C}$ for a week before using them.

Experiment 1 - We assessed the effect of deer presence on litter decomposition at the scale of an island through a reciprocal litterbag translocation experiment involving litter from the three islands representative of the three browsing treatments: "no", "intermediate" and "severe" browsing. We produced, for each plot, three identical litterbags for each of the two mesh-sizes. Each of these six litterbags contained, in the same proportion as in the plot, plant material from all plant species covering more than $5 \%$ of the plot area. As a result, our litterbags account for the variability in vegetation cover within each island. We fixed the total mass of litter per litterbag at $4 \mathrm{~g}$. Hence, we calculated the mass of litter from each plant species in a given litterbag according to its relative abundance in the plot. For each mesh size, we placed one of the three litterbags on the plot the litter came from ("home"), and placed the two remaining bags on one plot on each of the two remaining islands ("away"). This translocation allowed us to independently test for the relative effects of home- 
field advantage, of decomposer ability (soil properties and decomposer community composition), and of litter quality on litter decomposition (Appendix S1).

Experiment 2 - To investigate the influence of deer feces on litter decomposition rate within a litterbag, we used a standardized litter. We chose litter from one of the dominant tree species on all islands, $P$. sitchensis. To avoid any biases from potential inter-treatment differences in spruce litter quality, we used, for this set of litterbags, a mix of $P$. sitchensis litter collected from all three islands. In order to standardize feces quality, we collected fresh deer feces from another island with deer, also situated in Laskeek Bay (East Limestone, $48 \mathrm{ha}$ ). We used this material to place on each of the 45 plots one fine-mesh litterbag containing $2 \mathrm{~g}$ of deer feces and $2 \mathrm{~g}$ of the standardized litter and two fine-mesh litterbags containing controls, one filled only with $5 \mathrm{~g}$ of deer feces and one filled only with $2 \mathrm{~g}$ of $P$. sitchensis litter. We repeated this with coarse-mesh litterbags.

Thus, to implement these two experiments, we placed a total of 12 litterbags on each plot including 6 fine-mesh litterbags [3 for experiment 1 (1 home and 2 away) and 3 for experiment 2 (1 feces only $+1 P$. sitchensis only +1 with feces and $P$. sitchensis)] and a similar set of 6 litterbags for the coarse-mesh litterbags. As a result, we had a total of 540 litterbags (12 bags * 45 plots) for the full design. All litter bags were identified and numbered with aluminum tags and placed randomly on the surface of the forest floor on each plot. We used $U$ pins at each corner of the bag to hold them in place. We placed litterbags on the three islands in July 2017, and collected them one year later in July 2018. We considered a one-year duration optimal to incorporate the full range of weather conditions. The remoteness of the islands and associated logistical challenges to access the sites, especially from fall to spring, prevented designing an experiment with a partial collection of litterbags during the year to better assess the kinetics of decomposition. After collection (all but 35 bags were retrieved) we dried the litterbag contents at $70^{\circ} \mathrm{C}$ for $48 \mathrm{~h}$ prior to weighing the contents and then performing chemical analyses.

\section{Mass, Carbon and Nitrogen loss in litterbags}

To assess litter mass loss over a year in each litterbag we subtracted the final mass of the bag's content from its initial mass. We weighed the quantity of foreign material accumulated after a year in a control coarse-mesh litterbag displaced in each plot. We then subtracted this mass of foreign material from the final mass in coarse mesh litterbags, in order to correct for contamination. To assess 
$\mathrm{C}$ and $\mathrm{N}$ loss over a year, we calculated $\mathrm{C}$ and $\mathrm{N}$ contents of samples with an Elementar Vario El Cube Analyzer (Elementar, Langenselbold, Germany) using $3.5 \mathrm{mg}$ of ground material. We first calculated the initial $\mathrm{C}$ and $\mathrm{N}$ contents of dried litter using eight individuals of each plant species (vascular and bryophytes) from each island/browsing treatment. Based on these values, and on the relative proportion of each litter in the bags, we calculated the initial $\mathrm{C}$ and $\mathrm{N}$ content for each litterbag. We also measured initial $\mathrm{C}$ and $\mathrm{N}$ contents of eight deer pellet groups that were previously dried at $70^{\circ} \mathrm{C}$ for $48 \mathrm{~h}$.

At the end of the experiment we finely ground the dried litter from the fine-mesh litterbags only, to remain within our budget limitations, and measured $\mathrm{C}$ and $\mathrm{N}$ content. We calculated carbon and nitrogen loss by subtracting the amount of carbon and nitrogen remaining in litter after one year of decomposition from the initial estimates based on our calculations of initial $\mathrm{C}$ and $\mathrm{N}$ content of the litter material.

\section{Statistical analysis}

In order to evaluate the effect of deer herbivory on plant community composition we used a Correspondence Analysis on our data of plant species cover per plot, and performed a between class analysis (Dray and Dufour 2007). We evaluated the significance of the class effect with a permutation test. To assess the initial litter $\mathrm{C}: \mathrm{N}$ ratios at each plot we calculated the Community Weighted Mean (CWM) of this initial litter $\mathrm{C}: \mathrm{N}$ ratio using the formula

$$
C W M_{i}=\sum_{1}^{j}\left(C_{j} \times p_{j}\right) / \sum_{1}^{j}\left(N_{j} \times p_{j}\right)
$$

where $i$ represents the plot, $j$ the plant species on this plot, $C_{j}$ and $N_{j}$ the $\mathrm{C}$ and $\mathrm{N}$ content of the corresponding litter, and $p_{j}$ the relative abundance of the corresponding plant species on the plot.

We used one-way ANOVA with permutation tests to compare litter CWM C:N ratio, soil bulk density, soil $\mathrm{pH}$, soil $\mathrm{C}: \mathrm{N}$ ratio and organic horizon depth among the three islands. We used the multiple comparison post-hoc test with the function kruskalmc from the package pgirmess.

To assess differences in the rate of litter mass loss and of $\mathrm{C}$ and $\mathrm{N}$ loss in both experiments, we calculated the percent differences among treatments in litter mass loss and in $\mathrm{C}$ and $\mathrm{N}$ loss relative to the no-browsing treatment using the formula:

This article is protected by copyright. All rights reserved 


$$
100-\left(x_{\text {browsing }} \times 100\right) / x_{\text {no browsing }}
$$

Where $x_{\text {browsing }}$ is the litter, $\mathrm{C}$, or $\mathrm{N}$ mass loss in litterbags from either the intermediate or the severe browsing treatment, and $x_{\text {no browsing }}$ the litter, $\mathrm{C}$, or $\mathrm{N}$ mass loss in litterbags from the no browsing treatment.

Analyses of decomposition experiment 1 - We used a two-way ANOVA to compare litter mass loss, carbon loss and nitrogen loss from litter after one year among the three origins of litter (15 replicates from each island with no, intermediate or severe deer browsing) and among treatment categories (island with no, intermediate or severe deer browsing).

To disentangle the relative importance of the two main ways deer may modify $\mathrm{C}$ and $\mathrm{N}$ decomposition, namely litter quality and decomposer ability, we used the Decomposer Ability Regression Test proposed by Keiser et al. (2014) using SAS 9.4 (SAS Institute, Cary, NC). This method statistically discriminates among effects of litter quality (here defined as how rapidly a litter is decomposed regardless of decomposition site), ability [i.e. how rapidly a litter is decomposed at one site regardless of litter quality (includes the effect of soil abiotic conditions and the ability of the decomposer communities)] and home-field advantage [i.e. the acceleration of litter decomposition when litter is placed in the site it comes from (home) and where it can potentially benefit from a local specialization of the decomposer community]. The regression model defines the rate of decomposition of observation $\mathrm{i}\left(\mathrm{Y}_{\mathrm{i}}\right)$ by three parameters: litter quality $\left(\right.$ Litter $\left._{1}\right)$, soil ability $\left(\right.$ Soil $\left._{\mathrm{s}}\right)$, and HFA $\left(\right.$ Home $\left._{h}\right)$ which are dummy variables that equal 1 or 0 , respectively, depending on the presence or absence of the litter mixture, soil community and home combination (in observation i). The parameters to be estimated are $\beta_{\mathrm{l}}, \gamma_{\mathrm{s}}$ and $\eta_{\mathrm{h}}$ (Keiser et al., 2014). The average decomposition across all data (i) in a dataset, after controlling for litter, soil and home combinations, is represented by the intercept $(\alpha)$, and the error term is defined by $\varepsilon$. The $\beta_{1}$ and $\gamma_{s}$ are restricted to prevent collinearity.

$$
Y_{i}=\propto+\sum_{l=1}^{N} \beta_{l} \text { Litter }_{l_{i}}+\sum_{s=1}^{M} \gamma_{s} \text { Soil }_{s_{i}}+\sum_{H=1}^{K} \eta_{h} \text { Home }_{h_{i}}+\varepsilon_{i}
$$

Compared to the classically used Structural Equation Modeling (SEM), the Decomposer Ability Regression Test offers the additional possibility to explicitly test home-field advantage and maximizes the information extracted from the litter transplant experiment (Keiser et al. 2014).

This article is protected by copyright. All rights reserved 
To explore the reasons for differences in litter quality caused by deer, we performed linear models between $\mathrm{C}$ or $\mathrm{N}$ loss and litter CWM C:N ratio.

Analyses of decomposition experiment 2 (feces manipulation) - We used a two-way ANOVA to compare mass loss, $\mathrm{C}$ loss, and $\mathrm{N}$ loss of Picea sitchensis, feces and the combination of both.

For all analyses in which homoscedasticity and normality of the distribution of the residues were not respected, we used ANOVA with permutation tests instead of classical ANOVA (lmPerm package, Wheeler 2010).

We used the R 3.4.1 environment (R Core Team 2020) for all statistical analyses (except Decomposer Ability Regression Test).

\section{Results}

\section{Deer modify aboveground and belowground characteristics}

The first axis of the Correspondence Analysis on vegetation cover in the plots significantly discriminated the plant species composition and abundance in the plots according to the intensity of deer browsing (Fig. 1A, Monte-Carlo permutation test: p-value < 0.001). In the absence of deer, vegetation cover was higher and there was greater shrub diversity and heterogeneity among plots (Appendix S3). The vegetation from plots with severe deer browsing was characterized by a high cover and diversity of bryophytes (Fig. 1A) and limited variation in plant community among plots. Plots under intermediate deer browsing showed intermediate plant species diversity and cover, and intermediate heterogeneity among plot. We found no significant difference in the initial C:N ratio of the plant litter among deer browsing treatments (Fig. 1B, p-value $=0.2$ ). Soil bulk density was significantly higher on plots from islands with deer (Fig. 1C, p-value < 0.001). Soil pH was significantly different among deer browsing treatments (Fig. 1D, p-value $=0.04$ however statistical power was not sufficient to discriminate which treatment is different in the post-hoc test). Soil C:N was not significantly different among treatments (Fig. 1E, p-value $=0.32$ ). Depth of the organic horizon measured in the plots decreased by $44 \%$ with increasing browsing intensity (Fig. 1F, p-value $=0.005)$.

This article is protected by copyright. All rights reserved 


\section{Litter mass loss in experiment 1}

Litter mass loss was highest in litterbags with litter from the island with no deer and lowest in litterbags with litter from the island with severe browsing pressure (Fig. 2A). In fine-mesh litterbags average litter mass loss was 55\% in litter from the islands without deer, $43 \%$ for litter from islands with intermediate browsing pressure and 34\% in litter from islands with severe browsing pressure. This pattern held, whatever the island category litterbags were placed on (Fig. 2A). Variation, due to the context in which a given category of litter was placed, had only a little influence, and there was no significant effect of home-field advantage (Fig. 2B). Mass loss was significantly affected by the place of decomposition (Fig. 2A, F = 113.36, p-value $=0.05$ ). This pattern was due to a significantly enhanced ability of the micro-fauna and microorganisms from plots on the island without deer to decompose litter (Fig. 2C, p-value $=0.004$ ). Litter quality, was the main driver of carbon loss (Fig. 2D). Litter mixes originating from the island with no deer had the best quality index (highest loss after one year), followed by the litter mixes originating from the island with intermediate deer browsing and then by litter mixes originating from the island with severe deer browsing (Fig. 2D).

In coarse-mesh litterbags the overall patterns of decomposition were similar to those from finemesh litterbags (compare Fig.2 and Appendix S4), although variability among plots within sites was greater (Appendix S4). As a result, mass loss in litter mixes originating from islands with intermediate and severe deer browsing were, respectively, $25 \%$ and 39\% lower than in litter mixes originating from the plots on the island without deer (p-value < 0.001) (Appendix S4). There was no evidence for home-field advantage in large mesh litter bags (Appendix S4). Place of decomposition significantly affected litter mass loss (Appendix S4, F $=4.54$, p-value $=0.01$ ). The ability of the micro-fauna and microorganisms to decompose litter was significantly lower for litter placed in plots exposed to severe browsing (Appendix S4, p-value $=0.009$ ). As observed for fine-mesh litterbags, litter quality had a significant effect on litter decomposition in coarse-mesh bags (Appendix S4, p-value < 0.001).

\section{Carbon and Nitrogen loss in fine-mesh litterbags in experiment 1}

The loss of carbon in the litterbags after one year was highest for litter representative of the vegetation on islands without deer and lowest for litter representative of the vegetation on islands with the most severe browsing pressure (Fig. $2 \mathrm{E}, \mathrm{F}=108.78$, $\mathrm{p}$-value $<0.001$ ), a pattern consistent with the pattern of litter mass loss. When compared to the carbon loss observed in litter originating from the island 
with no deer, carbon loss after one year was $12 \%$ lower in litter collected from the island with intermediate browsing, and 30\% lower in litter collected from the island with severe browsing, this was independent of the incubating (i.e. island) context (Fig. 2E). Home-field advantage was not significant (Fig. 2F), indicating that decomposers were not more efficient in decomposing litter carbon when it originated from their own environment rather than from other sites. The ability of the micro-fauna and microorganisms to decompose carbon was significantly higher for litter placed in plots without deer than in plots on islands with deer (Fig. $2 \mathrm{G}$, p-value $=0.008$ ). Indeed, carbon loss after one year was 5\% lower in litterbags incubated in plots on the island with severe deer browsing than carbon loss observed in plots from the island without deer. Litter quality was the main driver of carbon loss. Litter mixes originating from the island with no deer had the best quality index (highest loss after one year), followed by the litter mixes originating from the island with intermediate deer browsing and then by litter mixes originating from the island with severe deer browsing (Fig. $2 \mathrm{H}$ ).

Litter mixes from the island without deer had significantly higher nitrogen loss than litter mixes from islands with deer (Fig. 2I). However, unlike C loss, nitrogen loss was lower for litter mixes originating from the island with intermediate deer browsing than that originating from the island with severe deer browsing (45\% and $28 \%$ respectively, Fig. $2 \mathrm{E}, \mathrm{F}=17.53$, p-value $<0.001)$. We detected no home-field advantage for $\mathrm{N}$ loss (Fig. 2J). In addition, none of the decomposer communities were better at decomposing and releasing nitrogen (Fig. 2K). Similar to what we observed for carbon, litter quality was the main driver of nitrogen loss in litter bags. However, conversely to carbon, the lowest rate of $\mathrm{N}$ loss after one year was observed in litter from the island with intermediate browsing pressure (Figs $2 \mathrm{H}$ and $2 \mathrm{~L}$ ).

Carbon and nitrogen loss in litterbags after one year were significantly and negatively related to the initial C:N ratio Community Weighted Mean (CWM) of the litter (Fig. 3). For litter carbon loss, the initial litter C:N CWM explained only 10\% of its variation (Appendix S5). Conversely, litter nitrogen loss was strongly linked to the initial litter C:N CWM, which explained $50 \%$ of its variability (Appendix S5).

\section{Feces decomposition in experiment 2}

The addition of feces enhanced the mass loss in P. sitchensis litter by $29 \%$ in fine-mesh (p-value $<0.001$, Fig. 4A) and marginally in coarse-mesh litterbags ( $p$-value =0.05, Appendix S6). In fine- 
mesh litterbags place of decomposition had marginal effect on feces mass loss (p-value $=0.06$, Fig. 4A). In coarse-mesh litterbags mass loss from feces was $15 \%$ higher on islands with deer than on islands without deer (Appendix S6, p-value < 0.001). Feces addition significantly increased the $\mathrm{C}$ and $\mathrm{N}$ loss in P. sitchensis litter after one year, by $31 \%$ for carbon and $47 \%$ for nitrogen (p-value $<0.001$ for both). There were no differences among place of decomposition in carbon and nitrogen loss from feces $(\mathrm{p}$-value $=0.26$ and $\mathrm{p}$-value $=0.66$ respectively, Fig. $4 \mathrm{~B}$ and $\mathrm{C}$ ). The ability of the decomposer community (i.e. decomposition place) had no effect on carbon loss (p-value = 0.587, Fig. 4B). However, for nitrogen loss in P. sitchensis litter, the presence of deer feces significantly improved the decomposition ability of the decomposer community in the plots from the islands with deer (p-value < 0.001, Fig. 4C).

\section{Discussion}

\section{Deer slow down decomposition mainly by changing understory plant communities}

In our study, we demonstrated that deer, through their impact on the understory vegetation, control the overall quality of litter reaching the forest floor, and consequently the decomposition process. We indeed demonstrated that this decrease in litter quality is the overriding factor governing litter decomposition in our study sites, rather than soil properties, composition of the soil decomposer community, or home-field advantage (Fig. 2).

The dramatic decrease in litter quality we observed is the result of an alteration in the understory plant community (Figs. 1A, 2H and 2L). Intense and prolonged deer browsing dramatically changed the understory plant composition and cover, resulting in an up to $90 \%$ reduction in understory shrub cover (Appendix S3, Fig. 1A). We found that this reduction in litter quality, and the associated modifications in the decomposition pattern, were only partly driven by the variation in the litter CWM C:N ratio (Fig. 3). This suggests that other parameters of litter quality not measured in our study, such as lignin or anti-herbivore compounds, were also involved in overall litter quality decline in presence of deer. Consequently we thereafter refer to the term 'litter quality' as a composite variable calculated as proposed by Keiser et al. (2014), and representing the rate of decomposition independent of decomposer ability and home-field advantage. The modifications of the understory vegetation we found not only confirm the severe impact of deer on Haida Gwaii (Martin et al. 2010, 
Chollet et al. 2013a), but are consistent with results in numerous other temperate forests (Côté et al. 2004, Boulanger et al. 2018), suggesting that effect of deer on the decomposition process through vegetation community shift may be widespread.

The major change in litter quality caused by deer browsing resulted, after one year, in an overall reduction in litter mass loss in presence of deer. This translated into a $30 \%$ lower carbon and a $28 \%$ lower nitrogen loss in litter from the island with severe browsing when compared to $\mathrm{C}$ and $\mathrm{N}$ losses in litter from the island with no browsing (Figs. 2E and 2I). This strong control of litter quality on C, and especially on $\mathrm{N}$ loss, contrasts with the previous assumption that vegetation changes may affect nitrogen and phosphorus dynamics less than the dynamics of carbon (Bryant et al. 1983, Wardle et al. 2002).

The prevailing role of decreased litter quality in litter decomposition we found in our system is in agreement with the microcosm study of Harrison and Bardgett (2003). They showed that decomposition of birch (Betula pubescens) litter, originating from inside deer exclosures (unbrowsed) in the Scottish Highlands decomposed faster than litter from outside of the exclosures (browsed), irrespective of the soil origin (inside or outside of exclosures). Conversely, Olofsson and Oksanen (2002), in a field translocation experiment assessing the decomposition of four plant species dominating the vegetation of lightly and heavily grazed tundra, demonstrated a positive effect of reindeer herbivory on decomposition rate.

\section{Decline in litter quality affects $C$ and $N$ cycles differently}

The decline in litter quality affected carbon and nitrogen cycles differently. For carbon, litter quality decreased as deer browsing intensity increased (Fig. 2H). For nitrogen, litter quality was poorer in the intermediate deer browsing than on the island with severe browsing (Fig. 2L). The decline in litter C loss could be explained by the shift from an understory dominated by more decomposable species (shrubs) towards an understory of less decomposable species (conifers and bryophytes) as the level of deer browsing intensity increased. Conifers and bryophytes are known to have slow decomposition rates due to low $\mathrm{N}$ content and high concentrations of structural carbohydrates and aromatic compounds (Cornwell et al. 2008, Turetsky et al. 2008). The presence of these secondary compounds may largely explain the lower decomposition of the litter from islands with deer and thus the slight effect of CWM of litter C:N ( $\approx 10 \%$ of variation explained, Fig. 3$)$. The contrasting result we obtained 
for $\mathrm{N}$ loss from litter after one year suggests that the vegetation shift caused by deer had different consequences for nitrogen mineralization. Although there was no overall significant difference in CWM litter C:N ratio among deer herbivory treatments, the intermediate treatment had the highest

values of $\mathrm{C}: \mathrm{N}$ (Fig. 3), which explains the lowest $\mathrm{N}$ loss values observed in this treatment $(\approx 50 \%$ of the variation is explained by $\mathrm{CWM}$ litter $\mathrm{C}: \mathrm{N})$.

\section{Deer also modify decomposer ability}

Although the decrease in litter quality caused by deer herbivory was identified as the main driver of the rate of litter mass and nutrient loss, several other changes in the soil decomposer communities affected nutrient cycling. Decomposers from the island without deer had a greater ability to decompose the carbon present in litter, but not nitrogen (Figs. $2 \mathrm{G}$ and $2 \mathrm{~K}$ ). The contrast between $\mathrm{C}$ and $\mathrm{N}$ decomposition among islands when using fine-mesh litterbags, and the similarity in $\mathrm{C}$ and $\mathrm{N}$ decomposition when using coarse-mesh litterbags (Appendix S4), suggest that the observed decomposition patterns are more likely explained by biotic differences in soils (i.e. differences in decomposer community) than by the effect of abiotic modifications such as higher soil compaction (Fig. 1C). A possible explanation for the observed contrasts in litter decomposition may be a switch in the bacterial:fungal ratio in presence of deer. In fact the disappearance of base-rich shrubs and their replacement by species with high concentrations of phenolic compounds (e.g. bryophytes) as a result of deer browsing may have increased the dominance of fungi which require less calcium and magnesium for growth (Prescott 2010). This change in decomposer community structure would favor the formation of a mor humus, in which up to $30 \%$ of the litter mass is converted to humus rather than decomposing (Prescott 2010). In addition the dramatic reduction in shrub cover may have reduced root exudation which stimulates bacterial activity (Ekberg et al. 2007). Contrary to carbon, the ability of decomposers to decompose nitrogen in litter did not vary among islands with different patterns of deer herbivory (Fig. 2K). This may be explained by the selection of microorganisms better able to exploit $\mathrm{N}$ in environments where this element is the most limiting ("nitrogen mining hypothesis", Craine, Morrow, \& Fierer, 2007) compensating for the switch in bacterial:fungal ratio. This hypothesis is supported by our control experiment, where we used a standardized quality of litter (Picea sitchensis), and found a greater ability of decomposers to decompose $\mathrm{N}$ in litter samples incubated on sites with deer (Fig. 4C).

This article is protected by copyright. All rights reserved 
Interestingly, we also found that the inclusion of the soil macro and mesofauna (hereafter fauna) in litter decomposition, via the use of coarse-mesh litterbags, affected litter mass loss (Appendix S4). Specifically, we found that litter decomposition was reduced on the island with the highest browsing intensity, suggesting a negative effect of deer on the faunal decomposer communities. Previous studies documented negative effects of large herbivores on the abundance and diversity of the soil fauna (see review by Andriuzzi \& Wall (2017)), but the consequences on litter decomposition were not studied. The negative effect we observed could be due to a reduction in both the abundance and the activity of the soil fauna through several mechanisms. Directly, through soil trampling by deer which might reduce soil fauna habitat through soil physical compaction and its reduction of soil pore size (Beylich et al. 2010). Indirectly, the reduction of litter quality by deer might be responsible for a slowing down of soil faunal abundance and activity for which litter quality is known to be a controlling factor (Hendriksen 1990, García-Palacios et al. 2013). As most previous studies on the effects of large herbivores on decomposition focused mainly on the role of microbes, we feel more attention needs to be paid to the role of the soil fauna in order to better understand ecosystem nutrient cycling.

\section{Dung and urine deposition effects on litter decomposition}

We found that soil fauna contributed significantly to the decomposition of deer feces, and observed evidence of home-field advantage (HFA). Indeed, deer feces decomposition in our study was more rapid on islands with deer (home) than on the island without (away), but only when including the effects of fauna (coarse-mesh bags, Appendix S6). We infer that deer have a positive effect on macrofauna decomposing dung. Such a positive effect of a deer species on this specialized fauna has been recently demonstrated in Japan where Iida, Soga, \& Koike (2018) found a positive relationship between the populations of dung beetles and deer density. In our study, we demonstrated that litter fauna, but not microorganisms, were selected for the decomposition of a particular litter type. This result highlights the importance of soil fauna in HFA, in agreement with the review of Austin et al. (2014) that suggests a significant role of soil meso and macro detritivores for this mechanism.

A large proportion of what we know on the effect of high-quality litter deposition (dung and urine) by large herbivores on nutrient cycling comes from the study of domestic animals and/or grassland ecosystems (McNaughton et al. 1997, Frank and Groffman 1998, Christenson et al. 2010).

This article is protected by copyright. All rights reserved 
We demonstrate that, in the temperate forests we studied, dung decomposed faster, and released a larger proportion of nitrogen, than observed for plant litter. Also, the addition of feces, whatever the mesh size, increased the rate of Picea sitchensis decomposition, increasing $\mathrm{C}$ loss by $31 \%$ and $\mathrm{N}$ loss by $47 \%$ (Fig. 4). This may be explained by the presence of labile nutrients in dung, which enhance the development of microbial communities, increasing rates of nutrient cycling (Bardgett, Keiller, Cook, \& Gilburn, 1998). However, despite these results, we found that high quality litter deposition did not affect overall decomposer ability (no higher decomposer ability on islands with deer dung/urine, Fig. $2 \mathrm{G}$ and $2 \mathrm{~K}$ ). This contradicts recent studies which demonstrated that feces deposition enhanced plant productivity and soil nutrient availability (Barthelemy et al. 2015, Wang et al. 2018). The explanation for the lack of effect in the forests we studied likely rests with the patchy distribution of solitary deer, in contrast to herding species like reindeer or livestock, and thus reflects the patchy, and limited, amounts of dung deposited locally at any given time, amounts that appear not to be sufficient to influence the nutrient cycling at the ecosystem level (Pastor et al. 1988).

\section{Conclusion}

Our results show that in temperate forests abundant deer may play an important role in ecosystem functioning, modifying not only aboveground characteristics, but also those belowground, and reducing nutrient cycling. In the last few decades, the awareness and knowledge of the effects of overabundant deer on aboveground communities has been growing worldwide (Côté et al. 2004, Takatsuki 2009). Our study suggests that these aboveground changes can potentially be at the root of modifications in nutrient cycling in temperate forest ecosystems. In addition, it has to be emphasized that our results are likely an underestimation of effects as we did not account the dramatic effect deer have on the quantity of litter reaching the forest floor. For example, in Europe the current 10 million roe deer Capreolus capreolus, in addition to the increasing populations of other ungulates, represent a standing biomass estimated at 0.75 billion $\mathrm{kg}$ that consumes $\approx 20$ million tons of green vegetation each year (Apollonio et al. 2010). Consequently, there is a critical need to expand our results to other temperate forests to assess the overall consequences increasing deer populations have on broad scale nitrogen cycling in soils (Hobbie and Villéger 2015) and their potential influence on global carbon storage (Tanentzap and Coomes 2012).

This article is protected by copyright. All rights reserved 


\section{Acknowledgments}

This study is part of the long-term research produced on Haida Gwaii by the Research Group on Introduced Species (RGIS). We want to thank Catch Catomeris, Maria Continentino, Yonadav Anbar, Barb Roswell and Max Bullock for their support in the field. This research was financially supported by the France Canada Research Fund (FCRF), University of Rennes 1 ("Défis scientifiques émergents"), the French Embassy in Canada, the French consulate in Vancouver and the Mitacs Globalink Research Award. The Research Group on Introduced Species provided financial and logistic support. The Laskeek Bay Conservation Society provided logistic support as did many members of the Haida Gwaii communities. We also acknowledge two anonymous reviewers for their useful comments on an earlier version of the manuscript. Statement of authorship: SC and MM contributed equally to this work; SC conceived the ideas and designed the methodology in close interaction with MM; SC, MM, JS and J-LM collected the data; MM and SC analyzed the data; SC and MM led the writing of the manuscript. All authors contributed critically to the drafts and gave final approval for publication.

\section{Supporting Information}

Additional supporting information may be found online at: [link to be added in production].

\section{References}

Andriuzzi, W. S., and D. H. Wall. 2017. Responses of belowground communities to large aboveground herbivores: Meta-analysis reveals biome-dependent patterns and critical research gaps. Global Change Biology 23:3857-3868.

Apollonio, M., R. Andersen, and R. Putman. 2010. European Ungulates and Their Management in the 21st Century. Cambridge University Press.

Austin, A. T., L. Vivanco, A. González-Arzac, and L. I. Pérez. 2014. There's no place like home? An exploration of the mechanisms behind plant litter-decomposer affinity in terrestrial ecosystems. New Phytologist 204:307-314.

This article is protected by copyright. All rights reserved 
Banner, A., W. H. MacKenzie, J. Pojar, A. MacKinnon, S. C. Saunders, and H. Klassen. 2014. A Field Guide to Ecosystem Classification and Identification for Haida Gwaii. Prov. B.C., Victoria, B.C. Land Manag. Handb. 68.

Bardgett, R. D., S. Keiller, R. Cook, and A. S. Gilburn. 1998. Dynamic interactions between soil animals and microorganisms in upland grassland soils amended with sheep dung: a microcosm experiment. Soil Biology and Biochemistry 30:531-539.

Bardgett, R. D., and D. A. Wardle. 2003. Herbivore-Mediated Linkages Between Aboveground and Belowground Communities. Ecology 84:2258-2268.

Barthelemy, H., S. Stark, and J. Olofsson. 2015. Strong Responses of Subarctic Plant Communities to LongTerm Reindeer Feces Manipulation. Ecosystems 18:740-751.

Beylich, A., H.-R. Oberholzer, S. Schrader, H. Höper, and B.-M. Wilke. 2010. Evaluation of soil compaction effects on soil biota and soil biological processes in soils. Soil and Tillage Research 109:133-143.

Boulanger, V., J.-L. Dupouey, F. Archaux, V. Badeau, C. Baltzinger, R. Chevalier, E. Corcket, Y. Dumas, F. Forgeard, A. Mårell, P. Montpied, Y. Paillet, J.-F. Picard, S. Saïd, and E. Ulrich. 2018. Ungulates increase forest plant species richness to the benefit of non-forest specialists. Global Change Biology 24:e485-e495.

British Columbia Ministry of Forests, Lands, and Natural Resource Operations. 2010. Biogeoclimatic Ecosystem Classification Codes and Names. Forest Analysis and Inventory Branch, Victoria, B.C.

Bryant, J. P., F. S. Chapin, and D. R. Klein. 1983. Carbon/Nutrient Balance of Boreal Plants in Relation to Vertebrate Herbivory. Oikos 40:357-368.

Chapin, F. S. I., P. A. Matson, and P. Vitousek. 2011. Principles of Terrestrial Ecosystem Ecology. Second edition. Springer-Verlag, New York.

Chollet, S., C. Baltzinger, L. Ostermann, F. Saint-André, and J.-L. Martin. 2013a. Importance for forest plant communities of refuges protecting from deer browsing. Forest Ecology and Management 289:470-477.

Chollet, S., C. Baltzinger, S. L. Saout, and J.-L. Martin. 2013b. A better world for bryophytes? A rare and overlooked case of positive community-wide effects of browsing by overabundant deer. Écoscience 20:352-360.

Chollet, S., C. Bergman, A. J. Gaston, and J.-L. Martin. 2015. Long-term consequences of invasive deer on songbird communities: Going from bad to worse? Biological Invasions 17:777-790.

Chollet, S., and J.-L. Martin. 2013. Declining woodland birds in North America: should we blame Bambi? Diversity and Distributions 19:481-483.

This article is protected by copyright. All rights reserved 
Chollet, S., S. Padié, S. Stockton, S. Allombert, A. J. Gaston, and J.-L. Martin. 2016. Positive plant and bird diversity response to experimental deer population reduction after decades of uncontrolled browsing. Diversity and Distributions 22:274-287.

Christenson, L. M., M. J. Mitchell, P. M. Groffman, and G. M. Lovett. 2010. Winter climate change implications for decomposition in northeastern forests: comparisons of sugar maple litter with herbivore fecal inputs. Global Change Biology 16:2589-2601.

Cline, L. C., D. R. Zak, R. A. Upchurch, Z. B. Freedman, and A. R. Peschel. 2017. Soil microbial communities and elk foraging intensity: implications for soil biogeochemical cycling in the sagebrush steppe. Ecology Letters 20:202-211.

Cornwell, W. K., J. H. C. Cornelissen, K. Amatangelo, E. Dorrepaal, V. T. Eviner, O. Godoy, S. E. Hobbie, B. Hoorens, H. Kurokawa, N. Pérez-Harguindeguy, H. M. Quested, L. S. Santiago, D. A. Wardle, I. J. Wright, R. Aerts, S. D. Allison, P. V. Bodegom, V. Brovkin, A. Chatain, T. V. Callaghan, S. Díaz, E. Garnier, D. E. Gurvich, E. Kazakou, J. A. Klein, J. Read, P. B. Reich, N. A. Soudzilovskaia, M. V. Vaieretti, and M. Westoby. 2008. Plant species traits are the predominant control on litter decomposition rates within biomes worldwide. Ecology Letters 11:1065-1071.

Côté, S. D., T. P. Rooney, J.-P. Tremblay, C. Dussault, and D. M. Waller. 2004. Ecological Impacts of Deer Overabundance. Annual Review of Ecology, Evolution, and Systematics 35:113-147.

Craine, J. M., C. Morrow, and N. Fierer. 2007. Microbial Nitrogen Limitation Increases Decomposition. Ecology 88:2105-2113.

Dray, S., and A.-B. Dufour. 2007. The ade4 Package: Implementing the Duality Diagram for Ecologists. Journal of Statistical Software 22:1-20.

Ekberg, A., N. Buchmann, and G. Gleixner. 2007. Rhizospheric influence on soil respiration and decomposition in a temperate Norway spruce stand. Soil Biology and Biochemistry 39:2103-2110.

Eldridge, D. J., M. Delgado-Baquerizo, S. K. Travers, J. Val, I. Oliver, K. Hamonts, and B. K. Singh. 2017. Competition drives the response of soil microbial diversity to increased grazing by vertebrate herbivores. Ecology 98:1922-1931.

Foster, C. N., P. S. Barton, and D. B. Lindenmayer. 2014. Effects of large native herbivores on other animals. Journal of Applied Ecology 51:929-938.

Frank, D. A., and P. M. Groffman. 1998. Ungulate Vs. Landscape Control of Soil C and N Processes in Grasslands of Yellowstone National Park. Ecology 79:2229-2241.

This article is protected by copyright. All rights reserved 
García-Palacios, P., F. T. Maestre, J. Kattge, and D. H. Wall. 2013. Climate and litter quality differently modulate the effects of soil fauna on litter decomposition across biomes. Ecology Letters 16:10451053 .

Gaston, A. J., S. A. Stockton, and J. L. Smith. 2006. Species-area relationships and the impact of deer-browse in the complex phytogeography of the Haida Gwaii archipelago (Queen Charlotte Islands), British Columbia. Écoscience 13:511-522.

Gholz, H. L., D. A. Wedin, S. M. Smitherman, M. E. Harmon, and W. J. Parton. 2000. Long-term dynamics of pine and hardwood litter in contrasting environments: toward a global model of decomposition. Global Change Biology 6:751-765.

Gill, R. M. A. 1992. A Review of Damage by Mammals in North Temperate Forests: 3. Impact on Trees and Forests. Forestry: An International Journal of Forest Research 65:363-388.

Golumbia, T., L. Bland, K. Morre, and P. Bartier. 2008. History and current status of introduced species on Haida Gwaii. Pages 8-31 Lessons from the islands: introduced species and what they tell us about how ecosystems work. Canadian Wildlife Service, Environment Canada. Gaston AJ, Golumbia TE, Martin JL, Sharpe ST, Ottawa.

Handa, I. T., R. Aerts, F. Berendse, M. P. Berg, A. Bruder, O. Butenschoen, E. Chauvet, M. O. Gessner, J. Jabiol, M. Makkonen, B. G. McKie, B. Malmqvist, E. T. H. M. Peeters, S. Scheu, B. Schmid, J. van Ruijven, V. C. A. Vos, and S. Hättenschwiler. 2014. Consequences of biodiversity loss for litter decomposition across biomes. Nature 509:218-221.

Harrison, K. A., and R. D. Bardgett. 2003. How browsing by red deer impacts on litter decomposition in a native regenerating woodland in the Highlands of Scotland. Biology and Fertility of Soils 38:393-399.

Haynes, R. J., and R. S. Swift. 1990. Stability of soil aggregates in relation to organic constituents and soil water content. Journal of Soil Science 41:73-83.

Hendriksen, N. B. 1990. Leaf litter selection by detritivore and geophagous earthworms. Biology and Fertility of Soils 10:17-21.

Hobbie, S. E., and S. Villéger. 2015. Interactive effects of plants, decomposers, herbivores, and predators on nutrient cycling. Page Trophic ecology: Bottom-up and top-down interactions across aquatic and terrestrial systems. Cambridge University Press. Torrance C. Hanley; Kimberley J. La Pierre, Cambridge.

Horsley, S. B., S. L. Stout, and D. S. DeCalesta. 2003. White-tailed deer impact on the vegetation dynamics of a northern hardwood forest. Ecological Applications.

This article is protected by copyright. All rights reserved 
Iida, T., M. Soga, and S. Koike. 2018. Large herbivores affect forest ecosystem functions by altering the structure of dung beetle communities. Acta Oecologica 88:65-70.

Keiser, A. D., D. A. Keiser, M. S. Strickland, and M. A. Bradford. 2014. Disentangling the mechanisms underlying functional differences among decomposer communities. Journal of Ecology 102:603-609.

Londo, G. 1976. The decimal scale for releves of permanent quadrats. Vegetatio 33:61-64.

Martin, J.-L., and C. Baltzinger. 2002. Interaction among deer browsing, hunting, and tree regeneration. Canadian Journal of Forest Research 32:1254-1264.

Martin, J.-L., S. A. Stockton, S. Allombert, and A. J. Gaston. 2010. Top-down and bottom-up consequences of unchecked ungulate browsing on plant and animal diversity in temperate forests: lessons from a deer introduction. Biological Invasions 12:353-371.

McNaughton, S. J., F. F. Banyikwa, and M. M. McNaughton. 1997. Promotion of the Cycling of DietEnhancing Nutrients by African Grazers. Science 278:1798-1800.

McShea, W., H. Underwood, and J. Rappole. 1997. The Science of Overabundance: Deer Ecology and Population Management. DC: Smithson. Inst. Press. Washington.

Milner, J. M., C. Bonenfant, A. Mysterud, J.-M. Gaillard, S. Csanyi, and N. Chr. Stenseth. 2006. Temporal and spatial development of red deer harvesting in Europe: biological and cultural factors. Journal of Applied Ecology 43:721-734.

Olofsson, J., and L. Oksanen. 2002. Role of litter decomposition for the increased primary production in areas heavily grazed by reindeer: a litterbag experiment. Oikos 96:507-515.

Pastor, J., B. Dewey, R. J. Naiman, P. F. McInnes, and Y. Cohen. 1993. Moose Browsing and Soil Fertility in the Boreal Forests of Isle Royale National Park. Ecology 74:467-480.

Pastor, J., R. J. Naiman, B. Dewey, and P. McInnes. 1988. Moose, Microbes, and the Boreal Forest. BioScience 38:770-777.

Penner, J. F., and D. A. Frank. 2018. Litter Decomposition in Yellowstone Grasslands: The Roles of Large Herbivores, Litter Quality, and Climate. Ecosystems.

Prescott, C. E. 2010. Litter decomposition: what controls it and how can we alter it to sequester more carbon in forest soils? Biogeochemistry 101:133-149.

R Core Team. 2020. R: A language and environment for statistical computing. R Foundation for Statistical Computing, Vienna, Austria.

Ritchie, M. E., D. Tilman, and J. M. H. Knops. 1998. Herbivore Effects on Plant and Nitrogen Dynamics in Oak Savanna. Ecology 79:165-177.

This article is protected by copyright. All rights reserved 
Royo, A. A., R. Collins, M. B. Adams, C. Kirschbaum, and W. P. Carson. 2010. Pervasive interactions between ungulate browsers and disturbance regimes promote temperate forest herbaceous diversity. Ecology.

Ruess, R. W., and S. J. McNaughton. 1987. Grazing and the Dynamics of Nutrient and Energy Regulated Microbial Processes in the Serengeti grasslands. Oikos 49:101-110.

Schrama, M., P. Heijning, J. P. Bakker, H. J. van Wijnen, M. P. Berg, and H. Olff. 2013. Herbivore trampling as an alternative pathway for explaining differences in nitrogen mineralization in moist grasslands. Oecologia 172:231-243.

Sitters, J., E. S. Bakker, M. P. Veldhuis, G. F. Veen, H. Olde Venterink, and M. J. Vanni. 2017. The Stoichiometry of Nutrient Release by Terrestrial Herbivores and Its Ecosystem Consequences. Frontiers in Earth Science 5.

Soil Classification Working Group / Groupe de travail sur la classification des sols. 1998. Canadian System of Soil Classification, 3rd Ed. NRC Research Press.

Stockton, S. A., S. Allombert, A. J. Gaston, and J.-L. Martin. 2005. A natural experiment on the effects of high deer densities on the native flora of coastal temperate rain forests. Biological Conservation 126:118128.

Sutherland Brown, A. 1968. Geology of the Queen Charlotte Islands, British Columbia. B.C. Ministry of Energy, Mines and Petroleum Resources Bulletin 54.

Takatsuki, S. 2009. Effects of sika deer on vegetation in Japan: A review. Biological Conservation 142:19221929.

Tanentzap, A. J., and D. A. Coomes. 2012. Carbon storage in terrestrial ecosystems: do browsing and grazing herbivores matter? Biological Reviews 87:72-94.

Terborgh, J., and J. A. Estes. 2013. Trophic Cascades: Predators, Prey, and the Changing Dynamics of Nature. Island Press.

Turetsky, M. R., S. E. Crow, R. J. Evans, D. H. Vitt, and R. K. Wieder. 2008. Trade-offs in resource allocation among moss species control decomposition in boreal peatlands. Journal of Ecology 96:1297-1305.

Vila, B., F. Torre, F. Guibal, and J.-L. Martin. 2004. Can we reconstruct browsing history and how far back? Lessons from Vaccinium parvifolium Smith in Rees. Forest Ecology and Management 201:171-185.

Wang, J., D. Wang, C. Li, T. R. Seastedt, C. Liang, L. Wang, W. Sun, M. Liang, and Y. Li. 2018. Feces nitrogen release induced by different large herbivores in a dry grassland. Ecological Applications 28:201-211.

This article is protected by copyright. All rights reserved 


\section{Figure Legends}

Figure 1. Effect of deer herbivory on aboveground (A, B) and belowground ( $C$ to $F)$ parameters. Shades of dots and barplots represent the deer browsing treatment with: light grey $=$ no browsing (deer absent), grey $=$ intermediate (deer present for over 70 years but exposed to significant culls) and dark grey $=$ severe browsing (deer present for over 70 years and not exposed to hunting). Small letters on each barplot indicate differences tested by non-parametric post-hoc test. Panel A - Correspondence Analysis on the vegetation data collected at each plot. Dots, squares and lozenges represent the coordinates of the plots from the islands with no browsing, intermediate browsing and severe browsing, respectively. Arrows indicate the species contributions to axes (one arrow per species). Plant species are classified according to their functional group; Panel B - Community Weighted Mean (CWM) of C:N ratio of the plant community; Panel C - Soil bulk density; Panel D - Soil pH; Panel E Soil C:N ratio; Panel F - Organic horizon depth.

Figure 2. Decomposition rate of the plant community litter among deer browsing categories for mass (top), carbon (middle) and nitrogen (bottom) in fine-mesh litterbags in the translocation experiment. Shades of barplots represent the deer browsing intensity with: light grey = no browsing (deer absent), grey $=$ intermediate (deer present for over 70 years but exposed to significant culls) and dark grey $=$ severe browsing (deer present for over 70 years but not exposed to hunting, highest deer density). Asterisks indicate estimates significantly different from zero with $*<0.05, * *<0.01, * * *<0.001$. Fine letters in each bar plots indicate differences tested by post-hoc test. Panel A, Panel E and Panel I represent mass, carbon and nitrogen loss after one year among treatments respectively with bars grouped according to litter origin and shades corresponding to the category of deer browsing of the location where the litter bags were placed. Panel B-D, F-H and J-L represent the parameter estimates $( \pm$ SE) calculated using the Decomposer Ability Regression Test proposed by Keiser et al. (2014). HFA $=$ Home-Field-Advantage . Ability $=$ decomposer ability, or the difference in decomposition rates of the same type of litter exposed to different decomposer communities (Keiser et al. 2014). Litter quality $=$ difference in decomposition rates among different litter types exposed to the same decomposer community (Keiser et al. 2014).

This article is protected by copyright. All rights reserved 
Figure 3. Linear regression of carbon (left) and nitrogen (right) loss variation with plant C:N Community Weighted Mean. Shades of dots represent the deer browsing intensity on the island where the litter came from, with: light grey = no browsing (deer absent), grey = intermediate (deer present for over 70 years but exposed to significant culls) and dark grey = severe browsing (deer present for over 70 years but not exposed to hunting, highest deer density). The shapes of the symbols refer to the browsing category of the island where we placed the litterbags. Details on regressions models are given in Appendix S5.

Figure 4. Mass, carbon and nitrogen loss in Picea sitchensis litter with and without the addition of feces and in feces alone, in relation to browsing treatment in fine-mesh litterbags. Shades of barplots refer to the deer browsing category of the place of decomposition with: light grey $=$ no browsing (deer absent), grey $=$ intermediate (deer present for over 70 years but exposed to significant culls) and dark grey $=$ severe deer browsing (deer present for over 70 years but not exposed to hunting, highest deer density). Panel A - Mass loss; Panel B - Carbon loss; Panel C - Nitrogen loss. Small letters above each barplot indicate differences tested by post-hoc test.

This article is protected by copyright. All rights reserved 
A
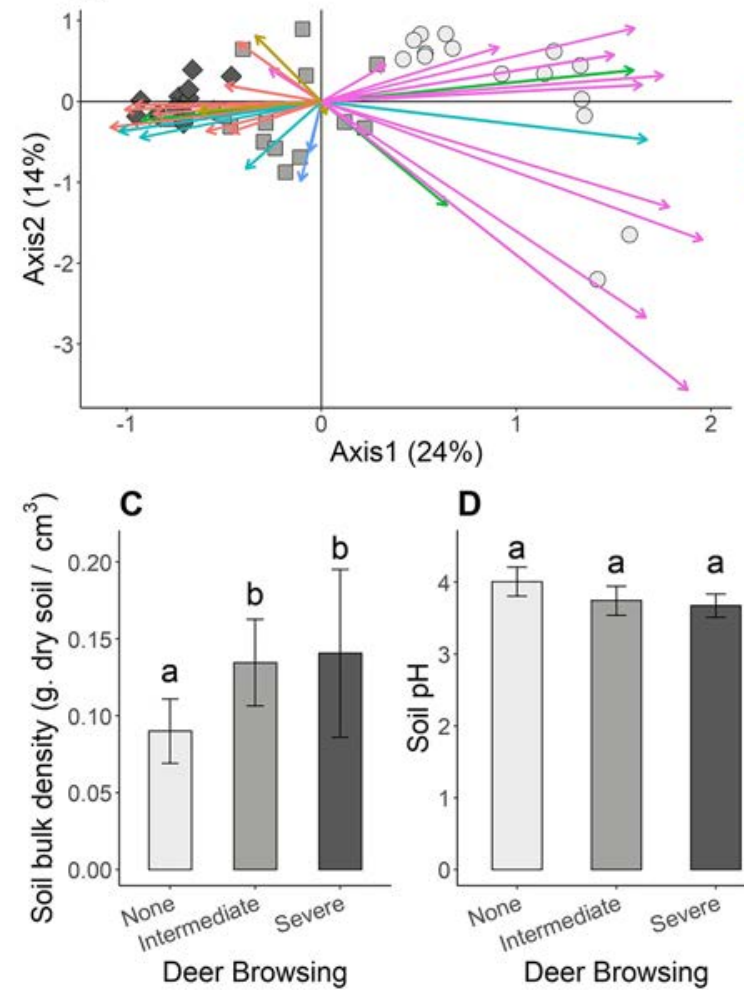

D

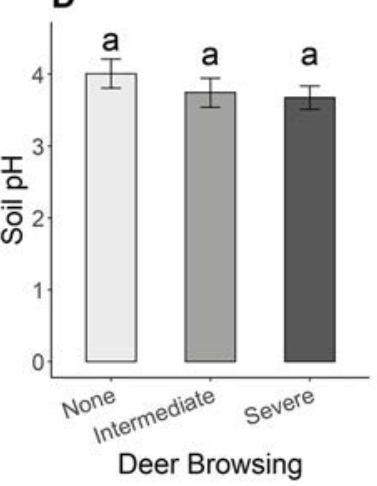

B
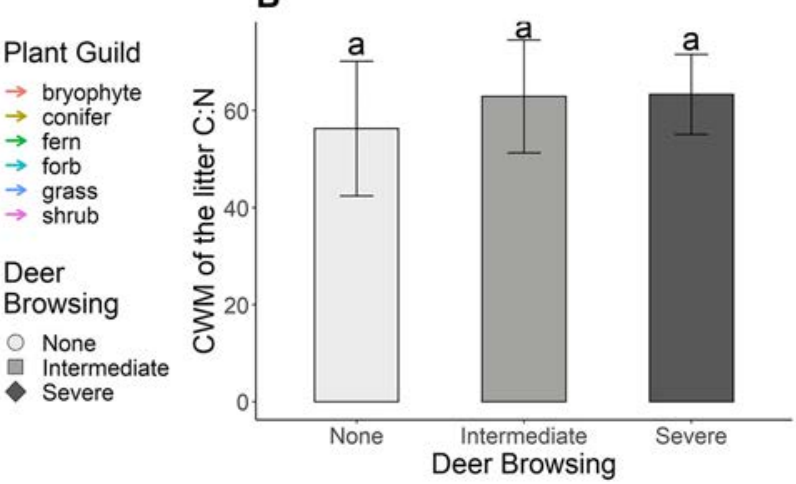

E
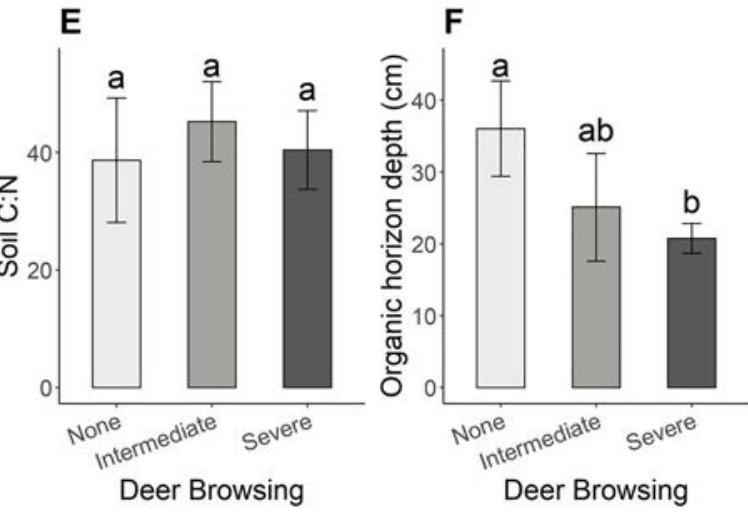

ecy_3235_f1.tif 

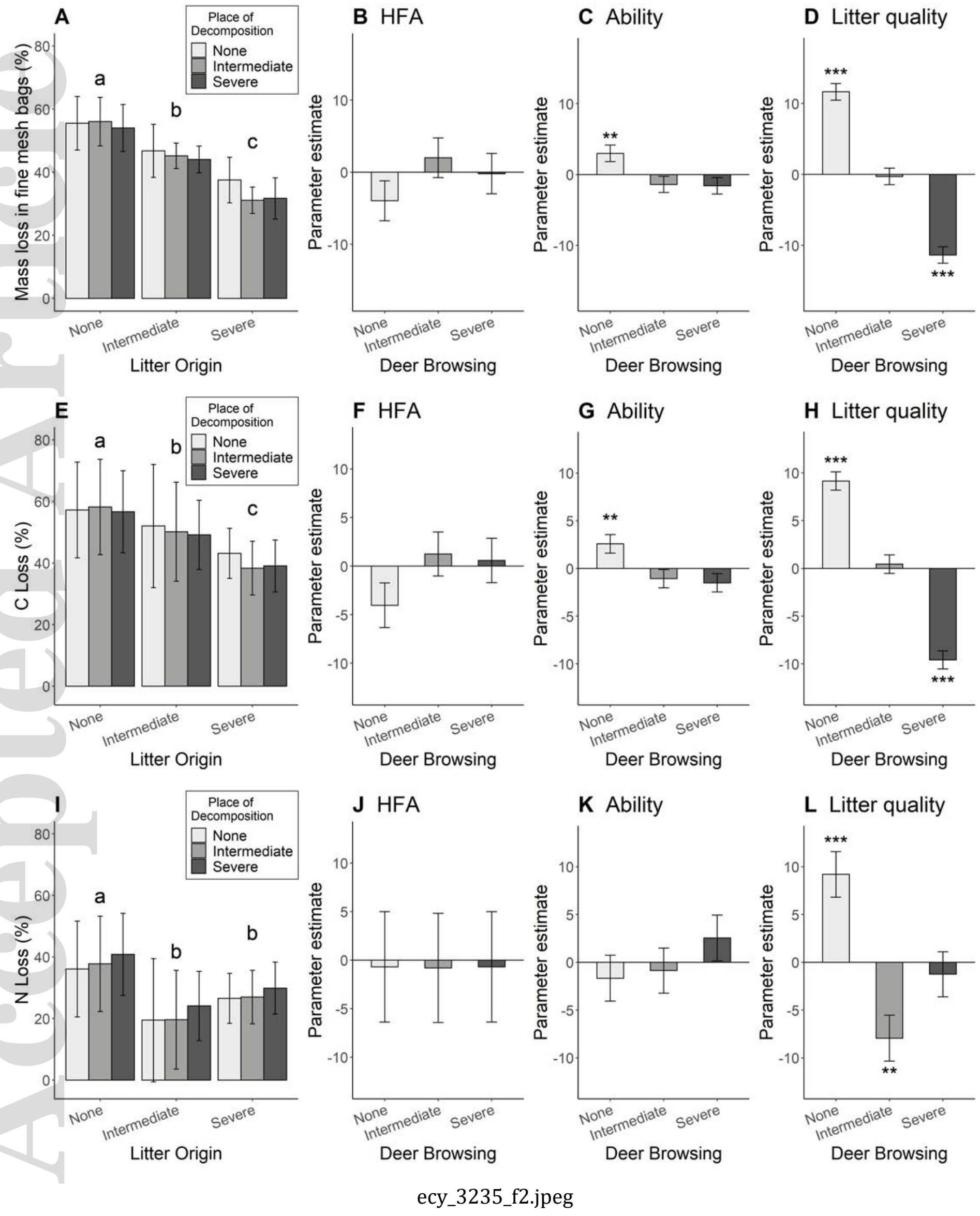

L Litter quality

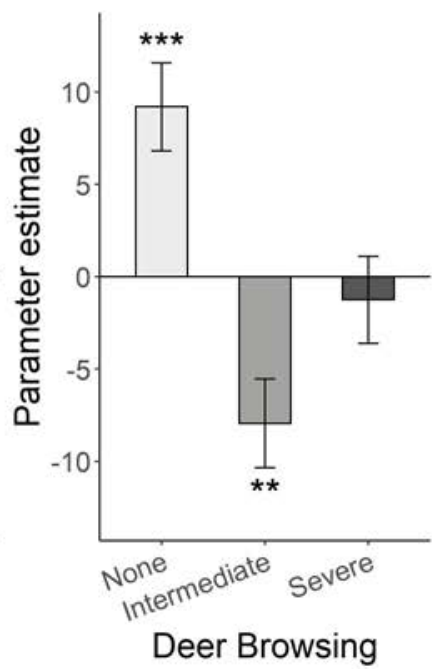

ecy_3235_f2.jpeg

This article is protected by copyright. All rights reserved 
A

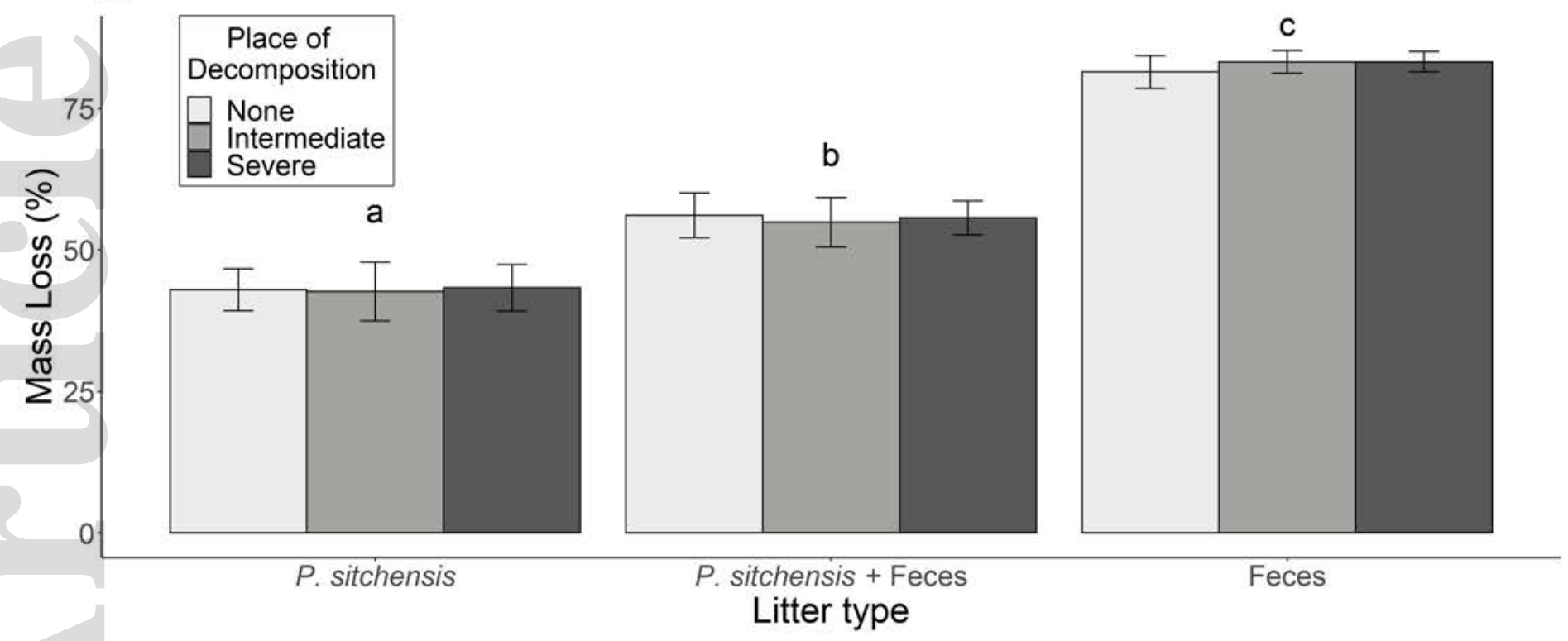

B

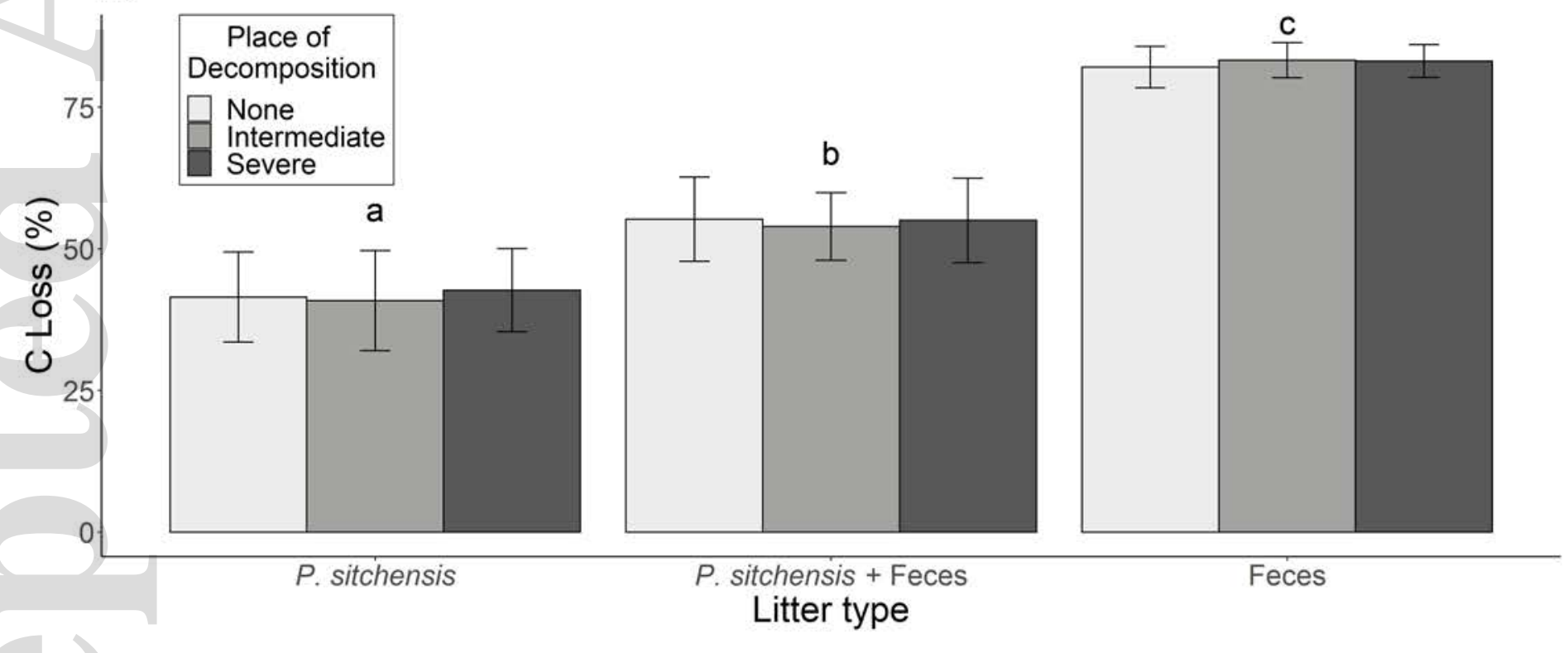

C

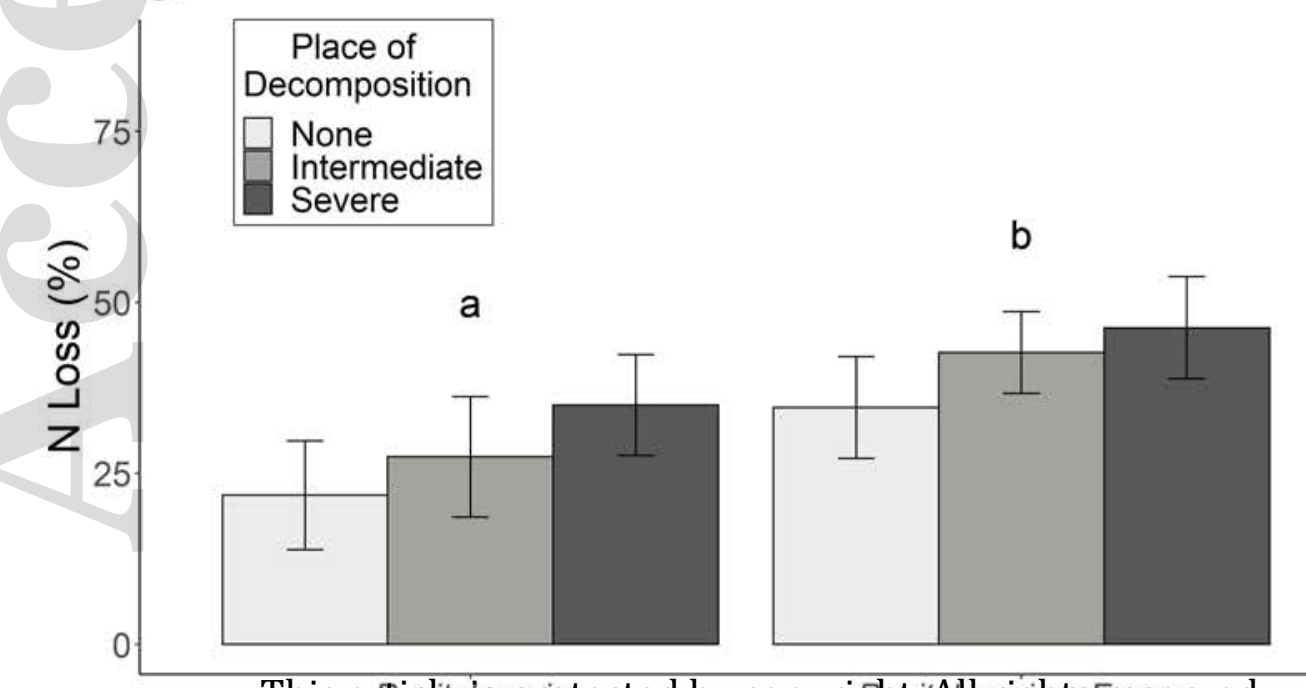

This areicliecisopsiotected by copyrightitAlbrights freserved Litter type

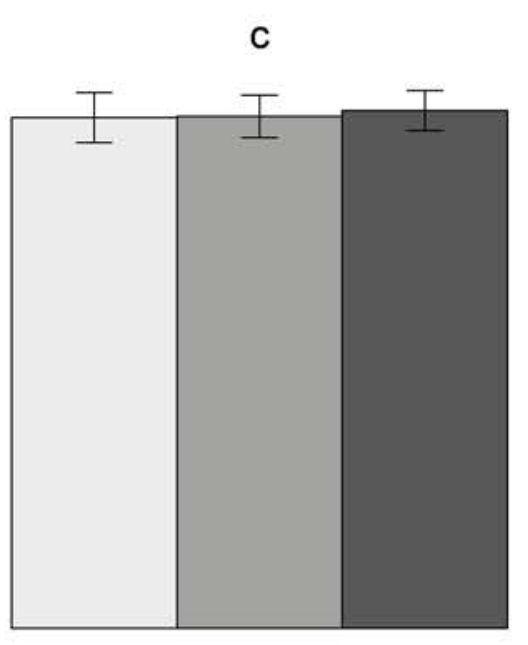

